\title{
Uncritical and unbalanced coverage of synthetic biology in the Nordic press
}

Public Understanding of Science 2017, Vol. 26(2) 235-250

(C) The Author(s) 2015

Reprints and permissions: sagepub.co.uk/journalsPermissions.nav

DOI: $10.1177 / 0963662515609834$ journals.sagepub.com/home/pus

@SAGE

\section{Mirko Ancillotti*}

Uppsala University, Sweden

\section{Niklas Holmberg* and Mikael Lindfelt}

Åbo Akademi University, Finland

\section{Stefan Eriksson}

Uppsala University, Sweden

\begin{abstract}
Synthetic biology will probably have a high impact on a variety of fields, such as healthcare, environment, biofuels, agriculture, and so on. A driving theme in European research policy is the importance of maintaining public legitimacy and support. Media can influence public attitudes and are therefore an important object of study. Through qualitative content analysis, this study investigates the press coverage of synthetic biology in the major Nordic countries between 2009 and 20I4. The press coverage was found to be event-driven and there were striking similarities between countries when it comes to framing, language use, and treated themes. Reporters showed a marked dependence on their sources, mainly scientists and stakeholders, who thus drives the media agenda. The media portrayal was very positive, with an optimistic look at future benefits and very little discussion of possible risks.
\end{abstract}

\section{Keywords}

media representations, public participation, science attitudes and perceptions, science communication, synthetic biology

\section{Introduction}

Synthetic biology (SB) is rapidly growing, and is anticipated to have a high impact on a variety of fields ranging from healthcare, environment, energy production and biofuels to agriculture, and so on. It can be defined as "the deliberate design and construction of customised biological and

*These two authors are the first co-authors and have contributed equally.

\section{Corresponding author:}

Mirko Ancillotti, Centre for Research Ethics \& Bioethics, Uppsala University, Husargatan 3, SE-75I 22 Uppsala, Sweden.

Email: mirko.ancillotti@crb.uu.se 
biochemical systems to perform new or improved functions" (IAP Global Network of Science Academies, 2014). Providing a definition of SB is always rather challenging. Asking 20 different experts to define it can bring about as many different perspectives, including those that would deny its independent existence (Arkin et al., 2009). This is partially due to the fact that SB is a relatively young field and to the fact that it cannot be seen as totally self-reliant; it ensues from the advancement in other fields such as genetic engineering, systems biology, molecular biology, and computational sciences (Joyce et al., 2013). This is mirrored both in how it is described and in the variety of issues provoked by it. The opinion on the definition of SB issued by the European Commission, which was adopted on 25 September 2014, is illustrative (Scientific Committee on Health and Environmental Risks (SCHER), Scientific Committee on Emerging and Newly Identified Health Risks (SCENIHR), Scientific Committee on Consumer Safety (SCCS), 2014). The committees adopted the following operational definition of SB: "the application of science, technology and engineering to facilitate and accelerate the design, manufacture and/or modification of genetic materials in living organisms" (SCHER, SCENIHR, SCCS, 2014). In the committees' opinion, this definition has the advantage of not excluding 40 years of risk assessment and safety guidelines produced in relation to genetic modification (GM) work. Moreover, the committees described the relationship between SB and GM as complicated because depending on the different reference points that are used (SCENIHR, SCHER, SCCS, 2015).

The development of SB may alter our very concept of life by challenging the basic scientific requisites of life as we know it (Forster and Church, 2007). It could thus make us reconsider our conceptual and moral understanding of life and of living beings (Deplazes-Zemp, 2012). In our view, this is not just hyperbole.

Usually, when a new technology enters the public sphere, it is compared to other technologies with which it is thought to share certain salient characteristics. Especially, science communicators identify the potential risks and benefits of the new technology comparatively. Science communicators may concern about tying SB to genetically modified crops and food because of its potential to reignite polarized discussions and debates on genetic engineering (Kronberger et al., 2012; Torgersen and Schmidt, 2013). One reason for promoting an early involvement of the public and for considering the ethical, legal, and social implications of SB originates from the worry that its public reception may be one of fear or major criticism. Claire Marris (2015) describes this preventive worry among stakeholders as "synbiophobia-phobia," and sees it as the "driving force behind the promotion of public engagement and other activities to address "ethical, legal and societal issues"' (p. 83). Therefore, it is important to investigate the actual or potential public perception and reaction to SB. Even so, the aim should not merely involve how to best present SB to make its products acceptable, but also to involve the public in building the conditions for making SB useful for and utilizable by society. Interpreted as such, investigating public attitudes toward SB ties in well with developments in Responsible Research and Innovation (RRI). This is a rather recent innovation concept introduced into the science and innovation governance by the European Union in which the ideas of early assessment and shaping research and development processes are incorporated along societal values and needs (Von Schomberg, 2011, 2013; see also Owen et al., 2012; Stilgoe et al., 2013). Different RRI framings have already been proposed for SB (Presidential Commission for the Study of Bioethical Issues (PCSBI), 2010; Synthetic Biology Roadmap Coordination Group, 2012; see also Brian, 2015; Li et al., 2015).

Public perceptions - especially in the context of this article - can be considered instruments for knowledge production in the course of an early societal assessment. The investigation of the ethical and social implications of SB can benefit from empirical data on how the public is informed, and about what. The media are a primary arena, with regard to both the selection of 
which issues to bring forth and how the issues are shaped (for the public, decision-makers, and interest groups) (Nisbet et al., 2003). Mass media not only informs the public but also shapes ideas about a number of issues (Kronberger et al., 2012; Scheufele, 1999; Valkenburg et al., 1999). They do this by underscoring specific facts or values, and by providing interpretive schemes (Nelson et al., 1997; Scheufele, 1999). Media thus have a noticeable social impact, but an undetermined one, as they typically reach an audience that is non-committed, fragmented, and busy with other things, not least finding entertainment (Dunwoody, 1987). So, the media can inform and educate citizens only to a certain extent, and in this they can give a more or less accurate description of the issue that might shape future deliberations. Investigating how SB has been described in the media is consequently of relevance and interest for society at large. Relevant to the present research-because it can be an indicator of the quality with which SB is conveyed to the public - is to understand whether SB in media coverage has reached a status as an issue per se, or if it is reported about only when playing some significant part of events that by themselves draw media attention. Moreover, in case a kind of status could be recognized, it would be interesting to consider whether SB is merely treated as another media commodity, as described by John C. Burnham (1987). Media commodities in the life sciences are continuously deployed and replaced by the next big thing, without there being any substantial change of relevance.

This study investigates empirical data on how SB was presented to the public of the four major Nordic countries (in terms of population), that is, Denmark, Finland, Norway, and Sweden, between 2009 and 2014. These countries were selected for two reasons. First, their research and investments in SB are on the rise, as witnessed by many facts. In the foresight strategic project FinnSight 2015 (2006), done in collaboration between Tekes (the Finnish Funding Agency for Innovation) and The Academy of Finland (an agency within the Ministry of Education, Science and Culture), seven areas of competence for Finland within biosciences were suggested. Four of these focus areas of competence are connected to SB, that is, management and modeling of biological knowledge, the development of pharmaceuticals, the development of bioproduction, and new biotechnological product introductions. The Swedish Foundation for Strategic Research (an agency within the public research founding system) also recommended in a strategy report for 2014-2017 that SB research should be implemented in Sweden (SSF, 2011). The Research Council of Norway is also clear in describing SB as an area to prioritize in their National Strategy for Biotechnology (NSFB) (2011-2020). In Denmark, two centers clearly connected to SB were started, the Centre for Synthetic Biology at the University of Copenhagen and the Novo Nordisk Foundation Center for Biosustainability at the Technical University of Denmark. The Nordic countries are also represented by The Innovation Found Denmark and Academy of Finland in the ERASynBio, an ERANET founded by the European Commission in 2012.

The second reason is that the Nordic countries have some of the world's highest newspaper subscription ratios (Kilman, 2012) and exhibit high trust in journalists' writings on biotechnology (Gaskell et al., 2010). Therefore, newspapers in the Nordic countries reach a large portion of the public and are considered authoritative in reporting on science and biotechnology.

This focus on the press coverage of SB in the Nordic countries is especially aimed at obtaining a balanced understanding of how SB was presented. Through a qualitative content analysis and by discussing selected issues found in the empirical material, this study elucidates the possible applications, benefits, and risks mentioned in relation to $\mathrm{SB}$, and also investigates how they were presented. It is of great interest to learn what metaphors, images, and models of explanation are used to further readers' understanding. The role of journalists' sources, primarily represented by the scientists involved in SB endeavors, will also be investigated, and commonalities with and differences to previous research will be highlighted. 


\section{Materials and methods}

A sample of 12 daily newspapers, published in the period 1 January 2009 to 31 December 2014, was analyzed. This period was selected based on the significant developments which characterized the field at this time, including the uptick represented by the publication of Synthia in 2010 and its aftermath. ${ }^{1}$ The three most widely read quality newspapers of each country were chosen. Since the objective was to learn what information the public received on SB by sources the public could perceive as trustworthy and not only entertaining, journalistic authority and reliability were used as criteria.

The data on circulation were attained from Dansk Oplagskontrol for Denmark, Media Audit Finland for Finland, Medie-Norge for Norway, and TS Mediefakta for Sweden. The selected newspapers were as follows: Berlingske, Jyllands-Posten, and Politiken (Denmark); Aamulehti, Helsingin Sanomat, and Turun Sanomat (Finland); Adresseavisen, Aftenposten, and Bergens Tidende (Norway); and Dagens Nyheter, Göteborg-Posten, and Svenska Dagbladet (Sweden). Both printed and online versions were considered. These newspapers can be considered to be among the most influential media in their respective countries, in respect to both informing the public and framing the topics in a way that influences other media.

The articles were collected retrospectively (with the exception of November and December 2014), using search terms in the respective national languages. Their equivalents in English are as follows: "artemisinin"; "artificial OR synthetic" and "bacterium OR cell OR DNA OR gene OR genome OR life OR molecule OR organism OR protein OR virus"; "biobased products"; "biobrick"; "bioengineer"; "biofuel"; "biohacker"; "biological machine"; "biosafety"; "bioterrorism"; "designer and organism"; "DNA synthesis"; "iGEM"; "minimal" and "genome OR organism"; "synthetic biology"; "XNA." The names of 20 globally and nationally renowned scientists were also used as search terms. The searches were done in newspapers' archives and through the media databases Mediearkivet, Infomedia, and PressText.

All stories which had a connection to SB were taken into account, but were put in three different categories (weak, medium, and strong), based on the weight SB had in the stories. The pertinence of the stories not directly mentioning SB was assessed using a variety of authoritative descriptions of what SB involves (Benner and Sismour, 2005; IAP Global Network of Science Academies, 2014; Schmidt et al., 2009).

This study was designed and conducted as a combination of qualitative and quantitative content analysis based on Philipp Mayring's approach (Kohlbacher, 2006; Mayring, 2000; see also Mayring, 2015). The texts of the articles were analyzed step by step, following rules of procedure. The system of categories was carefully set up and revised during the analysis. Each article was subjected to three analytical procedures, which were carried out in combination by reason of the relative brevity of the texts. The procedures were as follows: abstraction (reducing the material preserving the essential content), explication (creation of explicatory periphrases), and structuring (the material was processed, extracted, and inserted into a system of categories). The coding schedule and coding manual were designed on the basis of the literature and further implemented inductively. All articles were read twice and codified by two authors. After the first reading, new relevant categories and subcategories were added to the original schedule. The other authors independently rated a randomly selected subset $(21.5 \%)$ of the articles according to a "coding plan". Cohen's Kappa index was applied to calculate the inter-rater agreement, which was .84 .

Articles were coded according to their date of publication, length (short $<300$ words, medium 300-999, and long >999), and article type. Three main article types were considered: news, feature articles, and Editorials, Columns, and Opinion pieces (ECOs).

Articles were divided into two categories according to the narrative: thematic and episodic. The episodic frame presents issues as case studies, reports events, and focuses on concrete outcomes. 
The thematic frame instead presents issues in a broader, more general context, and focuses on longterm effects (Iyengar, 1991).

To catch the overall tone of the articles, that is, the general normative impression given by the story, the following tags were used: positive, negative, balanced, and cautious.

Another aspect investigated was whether articles were clear enough to enable the public to understand what SB is and to distinguish it from other biotechnologies. Within this analysis, only articles specifically mentioning "synthetic biology" were considered. Four categories were applied: clear, not clear, misleading, and missing (when no description was provided).

The language was analyzed with regard to both the recurrence of framing keywords and the types of metaphors and models encountered. QSR International's NVivo 10 software was used for producing a frequency word list out of all the articles, and based on these data a set of recurrent, framing keywords was pinpointed as the salient terms employed by the journalists to describe SB.

The content analysis encompassed the topics and fields of application contemplated in the articles, as well as the related risks and benefits. Evaluative labels were used to describe how the articles presented specific topics and applications: positive, negative, balanced, or if they were barely mentioned. Multiple topics and applications could occur in a single article; thus, they are not mutually exclusive.

Finally, the reasons for coverage were subsumed as events (e.g. conferences or scientific publications) or issues (SB as an issue, or topics related to $\mathrm{SB}$ ).

\section{Results}

\section{Coverage and journalistic frame}

Between 2009 and 2014, the 12 newspapers considered in this study covered SB with 146 articles, distributed as follows: 34 Danish, 42 Finnish, 24 Norwegian, and 46 Swedish (see Figure 1). Considering the weight SB had in these articles highlights a similar distribution among the countries, with the exception of Denmark — which had $13(38 \%)$ weak, $13(38 \%)$ medium, and only 8 (24\%) strong connected stories - while the other countries had on average $20 \%$ weak, $22 \%$ medium, and 58\% strong connected stories.

With regard to the length and type of articles, Denmark showed some major differences in comparison with the other countries, with $2(6 \%)$ short, $24(71 \%)$ medium, and $8(22 \%)$ long stories; and $10(29 \%)$ news, $22(65 \%)$ feature articles, and $2(6 \%)$ ECOs. The other countries had on average $38 \%$ short, $55 \%$ medium, and $7 \%$ long stories, and $32 \%$ news, $48 \%$ feature articles, and $20 \%$ ECOs.

Looking at the average of the narrative, there were $22 \%$ thematic and $78 \%$ episodic stories, with negligible national variations.

The term synthetic biology was present at least once in 14 Danish articles, 26 Finnish, 12 Norwegian, and only in 11 Swedish. From 2011, the use of the term became more frequent, almost doubling. The remaining stories, to different degrees, were about SB without ever actually mentioning it. In the stories mentioning SB, the clarity with which it was described was considered. Swedish newspapers were the least accurate in describing SB to their readers, with only one clear description, while the most accurate were the Finnish newspapers, scoring 15 clear articles. It was also investigated whether the journalists used hyped titles in comparison with the text, and this was detected in $13 \%$ of the cases (evenly distributed among the countries).

The overall tone of the articles was balanced $(50 \%)$ or positive $(37 \%)$, some were codified as cautious $(9 \%)$, and only $4 \%$ of all articles were negatively oriented, of which the vast majority were ECOs. 


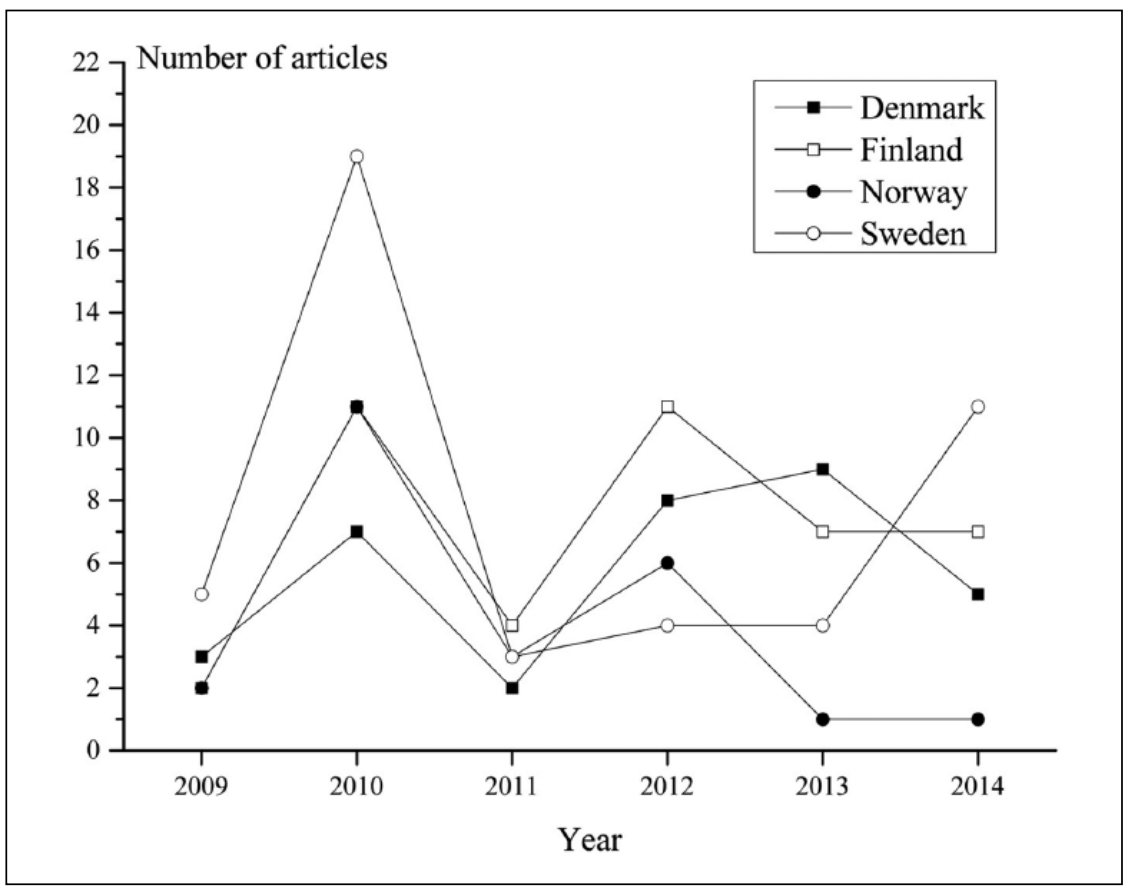

Figure I. Press coverage of synthetic biology in Denmark, Finland, Norway, and Sweden from 2009 to 2014.

\section{Themes}

Table 1 shows the themes (i.e. topics and fields of application) that were brought up.

The themes were often barely mentioned in the stories. They were mostly pointed to as potential fields in which SB can find application or as topics emerging from the practice of SB, but were not evaluated, further discussed, or problematized. "Balanced" was used when a theme was problematized or arguments for two opposite opinions were given with equal weight. Depending on the themes, the normative tone was implied differently. For example, while bringing up the possibility of bioterrorism always implied a level of concern, healthcare-related issues (e.g. new vaccines, drug production) or the potentiality of the field to provide new biofuels were always framed positively. Positive labels were attached to themes such as bioterrorism or biohazard when someone else's opinion on these subjects was reported, and excluded the possibility that SB could represent a source of danger or be misused.

Considering both the overall tone of the stories and the positive labels put on particular themes, the major benefits envisioned in the stories concern healthcare, the production of energy (biofuels), or the environment. The major risks considered were biohazard (accidental release of pathogens) and bioterrorism. It is noteworthy that only one article considering the risks of biohazards and bioterrorism was found to be negative in a general sense ("Gene Technology on Mail Order," 8 December 2010). ${ }^{2}$ In all other cases, the overall tone was cautious or balanced.

Despite being of interest for the academic debate, issues such as public involvement, calls for oversight, biodiversity, and religion-related issues found very little space in the stories examined. The variations between countries on the themes treated were minor, with the sole 
Table I. Frequencies of the different themes observed in the whole corpus of newspaper articles from 2009 to 2014 , differentiated by their normative tone.

\begin{tabular}{llccccc}
\hline$\#$ & Theme & Positive & Negative & Balanced & Mention & Total \\
\hline 1 & Healthcare & 28 & 1 & 4 & 44 & 77 \\
2 & Energy/biofuels & 24 & 1 & 7 & 31 & 63 \\
3 & Environment & 22 & 2 & 14 & 19 & 57 \\
4 & Economy/business & 7 & 7 & 5 & 25 & 44 \\
5 & Ethics & 2 & 3 & 25 & 8 & 38 \\
6 & Food and agriculture & 12 & 2 & 2 & 22 & 38 \\
7 & IT & 2 & 1 & 6 & 23 & 32 \\
8 & Research ethics & 3 & 5 & 14 & 7 & 29 \\
9 & Biohazard & 6 & 4 & 14 & 2 & 26 \\
10 & Legal & 1 & 2 & 12 & 6 & 21 \\
11 & Bioterrorism & 1 & 6 & 8 & 5 & 20 \\
12 & Oversight & 1 & 1 & 4 & 6 & 12 \\
13 & Biodiversity & 2 & 1 & 6 & 1 & 10 \\
14 & Religion & 0 & 0 & 3 & 3 & 6 \\
& Total & 111 & 36 & 124 & 202 & \\
\hline
\end{tabular}

deviations from the mean represented by a few themes in Finland and Sweden. In Finland, major weight was given to IT applications and environmental issues, but minor importance was given to the ethical dimensions of SB. In Sweden, on the other hand, ethical aspects of topics such as biodiversity, research ethics, and food and agriculture, were considered much more than in the other countries (Figure 2).

\section{Language, metaphors, and models}

The most recurring words in the corpus of all articles suggest a set of framing keywords that were preferentially employed by the journalists in describing SB. These were DNA, life, artificial, creation, genome, and bacteria. Besides these framing keywords, other keywords help to give an idea of what issues were related to the SB field; the name Venter was one of the most recurring words, and it is noteworthy that SB is situated in an academic research context through the frequent use of words such as research, researcher, professor, and scientific knowledge.

Investigating which figures of speech and interpretative models were most employed in the articles, we found that they were often optimistically oriented toward the future, commonly defining the progress of SB as a milestone in science and human knowledge.

While analogies to Legos were seldom used (only in $4 \%$ of the articles), the expression building blocks of life (or of DNA, or the genome) was preferred for communicating the level at which the researchers were working ( $17 \%$ of the articles). The dimension of playfulness, suggested through metaphors focusing on a tinkering with Legos, was not found relevant in the Nordic countries. More prominent were dimensions representing intentionality, that is, tailoring ( $21 \%$ of the articles) and the idea of design (34\% of the articles). This was often described as follows: " ... it is possible to tailor a bacterium. It can be put to do something completely different than what it was specialised in nature to do" ("Geneticist Can Tailor the Whole Genome of a Bacterium," 19 July 2011).

The Frankenstein motif was sometimes revived ( $8 \%$ of the articles), its primary function was to reassure readers that researchers were not creating a monster, for example, the author writes, "We 


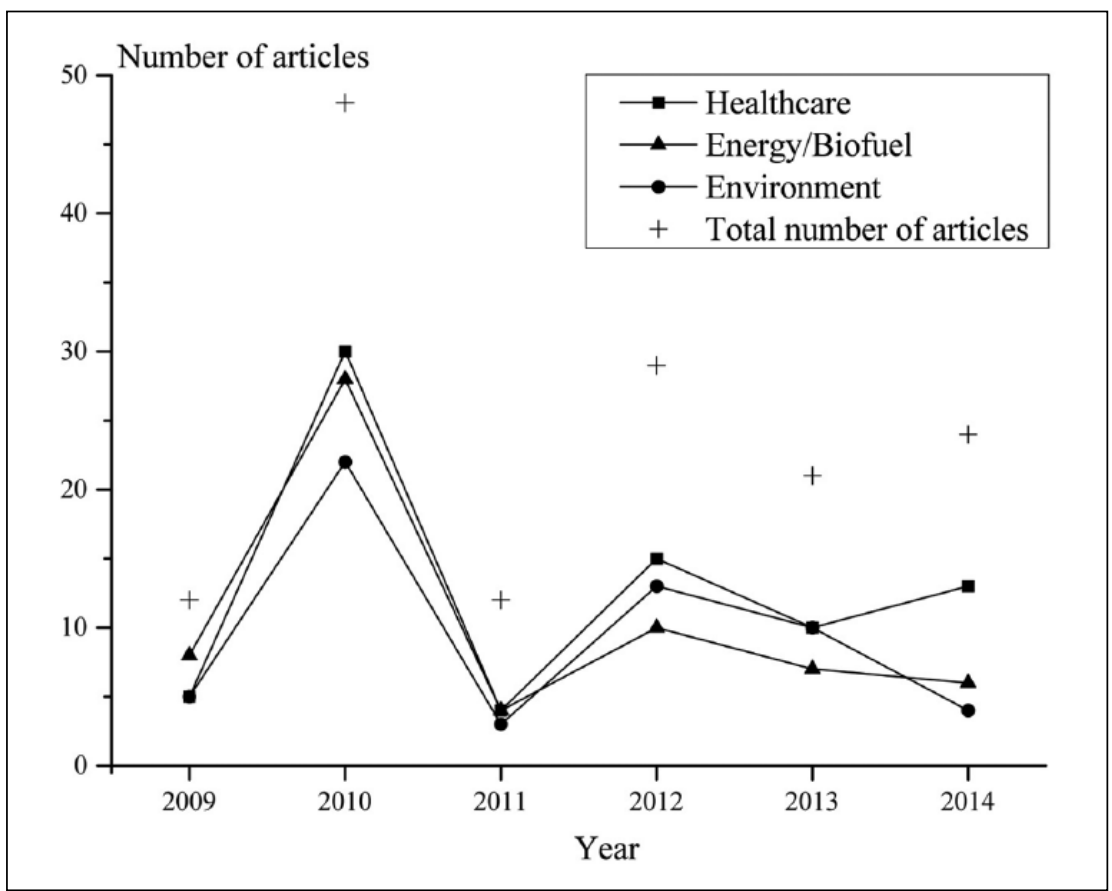

Figure 2. Occurrence of the three major themes in the articles per year.

are not talking about Frankenstein, but a totally synthetic ... bacteria culture..." ("Scientist created artificial life," 20 May 2010). The playing God argumentative scheme was sometimes resorted to ( $8 \%$ of the articles), but also in this case it was often specified that researchers were not engaged in such activity. As written in a Swedish article, "If Venter is playing God, it is only because mankind has always done it. The exaggerated expectations are probably unwarranted but so are the fears" ("Man Have Always Played God," 10 July 2010).

The explanatory models or analogies used to describe synthetic organisms often came from the industrial or IT sectors. Organisms were described in a mechanistic way as biological machines in $8 \%$ of the articles, for example, "Essentially, all living beings are biological machines, which read DNA and build themselves according to it" ("The Man Who Built Life," 24 July 2012), and occasionally as biological factories. The cells were more often described with reference to IT, with the cell being described as the hardware and the genome as the software, for example, "...the bacteria started to operate in accordance with the instructions contained in the software of the synthesized DNA..." ("Upheavals Tested Earth," 28 December 2010); this was found in $12 \%$ of the articles.

SB was often presented by stressing the creation of new entities or of life itself, often seen in titles such as "Researchers are creating artificial life" (20 May 2010), "The Midwife of Artificial Life" (24 July 2012), and in comments like "American researchers are first in the world to create an artificial lifeform in form of a bacterium" ("Researchers have created new life," 20 May 2010). This was found in 44\% of the articles. In $25 \%$ of the articles, scientists' work was presented as a creation, in 10\% it was explicitly written that SB outcomes should not be viewed as creations, and $9 \%$ of the articles raised it as a controversial issue inherent in the SB debate. 


\section{Discussion}

\section{Coverage}

The number of articles, their distribution in time, the narrative, and the reasons for coverage suggest that SB has only gained a sporadic resonance in the Nordic press. Compared to the United States and other European countries (Gschmeidler and Seiringer, 2012; Kruvand, 2013; Pauwels et al., 2012), the press of Nordic countries gave less attention to SB. Moreover, whereas media attention is dwindling in the Nordic countries, SB seems to attract more attention elsewhere, for example in English-speaking countries (Nerlich, 2014). Despite the relatively low interest shown by the media, Nordic countries are witnessing a growth in SB research, by both private and academic actors. Norway, for example, despite a dramatic drop in the last 2 years coverage, has set up many initiatives to attract companies. ${ }^{3}$

Results show that most articles had an episodic narrative and were based on a single event. As anticipated above, these circumstances reinforce the impression that journalists dedicate space to this field only when something resounding happens. Indeed, $33 \%$ of all the articles collected were written in 2010, and almost all were a report on, or a reaction to, the Craig Venter group's publication in Science: "Creation of a Bacterial Cell Controlled by a Chemically Synthesized Genome" (Gibson et al., 2010). The finding that more than 57\% of the articles about SB never mention it can be considered another indicator of the low relevance attributed to the field as an issue per se.

\section{Framing and sources}

Overall, SB was presented in a balanced or positive fashion rather than as something very controversial. The articles were generally quite similar regarding issues discussed, risks and benefits presented, and sources used. The use of the same sources is very likely to be the major reason for all the similarities encountered between the Nordic countries, which, in turn, show strong similarities to other countries whose media portrayal of SB has been analyzed in previous studies (Gschmeidler and Seiringer, 2012; Kruvand, 2013; Pauwels et al., 2012). If journalists do not filter the frames, content, and language used by their sources but instead rely heavily on them, the outcome is that the true shapers of ideas and attitudes toward SB are those who are directly involved with the field.

The major drivers of media attention were scientific events such as conferences, press releases, reports, and scientific papers. The articles in the corpus gave noticeable space to renowned scientists, mainly Craig Venter but also George Church and Jay Keasling, and particularly to their futuristic visions and their "professional speculations" (Schmidt et al., 2013). Examples are Venter suggesting the world to be doomed unless SB is employed to save it ("Craig Venter: We Need to Help Nature," 8 June 2010), and Church's vision of the resurrection of Mammoths and Neanderthals ("Wanted: Surrogate mother to Neanderthal baby," 20 January 2013).

Venter was the major catalyst of media attention, and was mentioned at least once in $44 \%$ of the articles (71\% between 2009 and 2010). His personality was uniquely commented on and he was depicted as controversial, as someone who likes competition, a showman, the bad boy of genetics, and of course a leading researcher. Despite the controversial descriptions, Venter heavily contributed to attracting media attention and to the framing of the field, for example by copiously using the expression "creation of artificial life" and its variants. This is a communication strategy, and was adopted by many influential scientists (Balmer and Herreman, 2009), which made good copy for journalists and publicity for the sources. In announcing the "creation" of Synthia, Venter managed to get the media to basically repeat the words, frames, figures of speech, and topics he used in his press release and public address (J Craig Venter Institute (JCVI), 2010; Venter, 2010). 
As noted by Martin Bauer, biomedical news is often characterized by personalization and resorts to expert voices more than other science news (Bauer, 1998). SB is similar in this regard, according to this study. A possible explanation as to why media coverage turned speculative is the absence of commercial products to accentuate, and a lack of public experience of SB, together with a need to popularize the field in question. Arguments of futuristic speculations are not always self-evident, and the frequency of expert citations could be regarded as something used in order to "imbue the argument with authority and legitimacy, to enhance and to embellish" (Bauer, 1998: p.739).

A method sometimes employed by journalists to balance the articles entailed introducing another scientist to comment on the issue. As a result, scientists preferred to describe Synthia as an organism with a synthetic genome, but not as a synthetic organism.

Another way journalists balanced the articles was to use binary contrasts, whereby a scientist was contrasted with non-scientists. Interestingly, the journalists seldom presented criticisms on their own behalf, but instead usually referred to an external source, that is, an ethicist or an environmentalist. This source was often Julian Savulescu, whose comments were more or less implicitly assumed to be the voice of bioethics. As noted by Marjorie Kruvand, bioethicists are generally presented as "interchangeable experts with a unified perspective" (Kruvand, 2012). Journalists prefer external reviewers because of their neutral role in science news, which differs from other fields of journalism such as sport, economy, or art criticism, in which journalists are often highly opinionated (Murcott, 2009).

As a consequence of scientists being the main sources of SB framing, the media portrayed it as a field driven by altruistic intentions, internally connected with addressing the most challenging concerns of our time, from alternative energy production to health-related issues. It has been argued that minimizing profit motives and promoting grand societal promises generate public alienation, and that presenting commercial purposes and motives does not lead to a skeptical public per se but rather that their absence provokes alienation and distrust in the public (Marris, 2015). However, the frequent mention of companies and economic aspects needs to be balanced against the fact that the framing keywords (professor, researcher, university) suggest a stronger connection of SB to the context of public research than to private sectors.

\section{Themes}

Scientists' communication is more effective in attracting media attention and in influencing policy when it relates to issues the public already prioritizes (Nisbet and Scheufele, 2009; Upham and Dendler, 2015). Not surprisingly, then, the most frequent topics and fields of application found in relation to SB were healthcare, the environment, and energy/biofuel production. Moreover, it is noteworthy that the major benefits envisioned in the articles overlap with the most treated topics. The influence of journalistic sources is also evident in the choice of the themes to bring to the general attention. The communication of scientists and other stakeholders never took place as a reaction to a crisis, but was always based on proactive communication, by the scientists, and is consequently positively framed and future-oriented (Schmid-Petri et al., 2014). In doing so, however, journalists do run the risk of conveying to readers the notion that SB is already fulfilling — or will soon fulfill - these practical expectations, which is far from reality.

The possible risks in relation to SB, mainly biohazards and bioterrorism, were mentioned only a few times, receiving much less consideration in both quantity and weight (they were presented neutrally) than the positive themes. Marjorie Kruvand observed that in the stories mentioning both risks and benefits, the former tended to be mentioned near or at the end of the stories (Kruvand, 2013). Our findings converge with Kruvand's observations, which, considering that Kruvand's study concerns the United States and different media outlets, reinforces the ideas that the media 
agenda regarding SB is de facto set by scientists and stakeholders in their function of primary sources of the stories. In marked difference to the media portrayal, academic studies and policy reports usually display a more balanced consideration of both benefits and risks.

Although, scientifically speaking, plant SB is an important part of SB (Liu and Stewart, 2015), there was much more focus on healthcare issues and very little emphasis on food and plant SB. It should be considered that the public has a very different attitude toward the latter than the former. People seem to be highly reluctant to put "biotechnological" food on their table, but are very keen to accept the results of the same technologies when they involve disease-treating drugs. For example, in the articles no criticism was found of the use of SB for the production of artemisinin (Ro et al., 2006), an anti-malarial drug precursor (this is a frequently mentioned example of SB's practical outcome, which was achieved by Keasling's group). Therefore, journalists did not consider the objections pointing at the fact that this new way to produce the drugs can harm the interests of the farmers who grow Artemisia annua (sweet wormwood) from which the drug is extracted, an objection presented by non-governmental organizations (NGOs) (ETC Group, 2014; Friends of the Earth, 2012). This contrast today is greater than ever (Gaskell et al., 2011). This can be seen as a core challenge for future communication regarding SB: How to responsibly report future agricultural applications alongside the promises of healthcare applications.

On a related note, what was very rarely mentioned in relation to SB was the involvement of the public or the need for an oversight of SB. On the contrary, in academic and other settings, the debates about the ethical, societal, and legal dimensions of SB often raise the necessity to involve the public.

\section{Language and metaphors}

The language, metaphors, and analogies used show a tendency by journalists to use established expressions from other biotechnological areas. Such a use of metaphors and interpretative models is a traditional feature of the scientific journalism jargon. Another such feature is to present new scientific developments as exciting breakthroughs or even as paradigm shifts. By emphasizing the possible applications, and using a language involving optimistically future-oriented metaphors such as "scientific revolution" and "milestone," journalists do risk creating excessive expectations. This tendency to hype and create expectations is often seen as one of the major challenges in science communication (Nerlich et al., 2009). The articles' content was often more balanced when a local scientist commented on and contextualized news of international relevance.

The media's use of figurative language when describing and making sense of SB and other biotechnologies is well known (Gschmeidler and Seiringer, 2012; Hellsten and Nerlich, 2011; Scheufele and Lewenstein, 2005). The same metaphors and explanation models could be spotted in all the Nordic countries, with only negligible differences.

The most prominent metaphors related to construction, whereby SB was described as the design and creation of new organisms through standardized parts as bricks or blocks or, more seldom, as Legos. This finding diverges from previous studies in which the Lego metaphor was found of relevance (Gschmeidler and Seiringer, 2012; Kruvand, 2013). Cserer and Seiringer observed that experts describe SB in terms of its "engineering work culture," and this is reflected in the epithets used by journalists to describe scientists, such as architects, engineers, and designers (Cserer and Seiringer, 2009).

The second most recurrent set of metaphors related to IT language, whereby the cell was described as the hardware and the genome as the software. Venter, for example, in his highly related press release and speech announcing the "creation" of the first synthetic cell, described it as the first organism with computers as parents (JCVI, 2010; Venter, 2010). The media simply echoed these words. 
Metaphors and models implying that SB challenges culturally entrenched distinctions (e.g. natural and unnatural) were rather frequent, and were evoked by expressions such as "the Frankenstein monster" and "scientists playing God." The most commonly used expression of this kind was "creation of life" or its variants, which was among the most recurrent expression in the headlines besides being discussed as both an ethical and a technical issue. The referral to SB products as creations may also be interpreted as driven by a will to attract venture capital and as a way to describe SB as an exciting paradigm shift (Arkin et al., 2009). Irrespective of the frequent presence of these expressions and images, only seven articles entertained the possibility of interpreting SB as unnatural. This is not wholly unexpected, as pointed out by Pardo et al.: the goals of a biotechnology can be assumed to play a more important role in public acceptance than its methods or the technology itself (Pardo et al., 2009). Their research indicates that questions of naturalness and unnaturalness are abstract and ideological arguments to which the public often does not adhere (Pardo et al., 2009). Besides, the images of Frankenstein and the playing God leitmotivs were often evoked in our material to negate alleged problems or to ironically describe objections to the progress of SB, for example, "now people will see green Frankenstein monsters in every corner" ("Managing life," 15 June 2010).

\section{Conclusion}

To date, SB has not gained any great media resonance in the Nordic press. There are not many articles, drivers of attention are mainly events, and the overall impression is that the field is treated as a media commodity.

Nordic newspapers were found to be rather unbalanced in their choice and presentation of the envisioned applications of SB and its potential benefits and risks. While SB potential benefits were highlighted, the potential risks were downplayed.

There were a few differences between the countries, mostly of a quantitative kind. The frame, tone, and language presented striking similarities, which seems ascribable to a marked dependence on the way scientists frame their accomplishments and to a lack of critical scrutiny by the media. The metaphors and themes used to convey information and news on SB did not present any remarkable differences to the terminology routinely employed when reporting about biotechnologies in general, except for the fact that the creational dimension of the SB endeavor was particularly emphasized.

The surveyed media did not actively promote or suggest any form of public involvement in the SB discourse. The portrayal of SB offered to the public is very positive, and is that of a biotechnology holding great potential to improve the human condition at many levels, with only minor risks relating primarily to malicious external agents or accidental events.

\section{Acknowledgements}

Mirko Ancillotti and Niklas Holmberg are co-first authors.

\section{Funding}

This study was partially funded by the ArtFilm project of the Academy of Finland.

\section{Notes}

1. The mycoplasma mycoides JCVI-syn1.0 obtained by Craig Venter's group at J Craig Venter Institute is often dubbed Synthia.

2. The titles and the excerpts from the newspapers were translated into English language by the authors.

3. http://indbiotech.no/events/developing-biobased-industry-norway- $\% \mathrm{E} 2 \% 80 \% 93$-lines-future 


\section{References}

Arkin A, Berry D, Church G, Arnold F, Boldt J, Müller O, et al. (2009) What's in a name? Nature Biotechnology 27(12): 1059-1194.

Balmer A and Herreman C (2009) Craig Venter and the re-programming of life: How metaphors shape and perform ethical discourses in the media presentation of synthetic biology. In: Nerlich B, Elliott R and Larson B (eds) Communicating Biological Sciences: Ethical and Metaphorical Dimensions. Farnham: Ashgate Publishing Company, pp. 219-234.

Bauer M (1998) The medicalization of science news-From the "rocket-scalpel" to the "gene-meteorite" complex. Social Science Information 37(4): 731-751.

Benner SA and Sismour AM (2005) Synthetic biology. Nature Reviews Genetics 6(7): 533-543.

Brian JD (2015) Special perspectives section: Responsible research and innovation for synthetic biology. Journal of Responsible Innovation 2(1): 78-80.

Burnham JC (1987) How Superstition Won and Science Lost: Popularizing Science and Health in the United States. New Brunswick, NJ: Rutgers University Press.

"Craig Venter: We Need to Help Nature" (2010) Dagens Nyheter, 8 June. Sve: "Craig Venter: Vi måste hjälpa naturen."

Cserer A and Seiringer A (2009) Pictures of synthetic biology. Systems and Synthetic Biology 3(1-4): 27-35.

Deplazes-Zemp A (2012) The conception of life in synthetic biology. Science and Engineering Ethics 18: 757-774.

Dunwoody S (1987) Scientists, journalists, and the news. Chemical \& Engineering News 65(46): 47-49.

ETC Group (2014) Artemisinin \& synthetic biology—A case study. Available at: http://www.etcgroup.org/ sites/www.etcgroup.org/files/ETC-artemisinin-synbio-casestudy2014.pdf

FinnSight 2015 (2006) The Outlook for Science, Technology and Society. Helsinki: Suomen Akatemia. Tekes. Available at: http://www.tekes.fi/globalassets/julkaisut/finnsight_2015_en.pdf

Forster AC and Church GM (2007) Synthetic biology projects in vitro. Genome Research 17(1): 1-6.

Friends of the Earth (2012) Synthetic biology: A threat to biological diversity. Available at: http://www.synbiowatch.org/wp-content/uploads/2012/09/Synthetic_Biology_101_CBD_1_-1.pdf

Gaskell G, Allansdottir A, Allum N, Castro P, Esmer Y, Fischler C, et al. (2011) The 2010 Eurobarometer on the life sciences. Nature Biotechnology 29(2): 113-114.

Gaskell G, Stares S, Allansdottir A, Allum N, Castro P, Esmer Y, et al. (2010) Europeans and Biotechnology in 2010: Winds of Change? Luxembourg: Publications Office of the European Union.

"Gene Technology on Mail Order" (2010) Aftenposten, 8 December. Nor: "Genteknologi på postordre."

"Geneticist Can Tailor the Whole Genome of a Bacteria" (2011) Helsingin Sanomat, 19 July. Fin: "Geneetikko voi räätälöidä bakteerin koko perimää."

Gibson DG, Glass JI, Lartigue C, Noskov VN, Chuang R-Y, Algire MA, et al. (2010) Creation of a bacterial cell controlled by a chemically synthesized genome. Science 329(5987): 52-56.

Gschmeidler B and Seiringer A (2012) "Knight in shining armour" or "Frankenstein's creation"? The coverage of synthetic biology in German-language media. Public Understanding of Science 21(2): 163-173.

Hellsten I and Nerlich B (2011) Synthetic biology: Building the language for a new science brick by metaphorical brick. New Genetics and Society 30(4): 375-397.

IAP Global Network of Science Academies (2014) IAP statement on realising global potential in synthetic biology: Scientific opportunities and good governance. Available at: http://www.interacademies.net/ File.aspx?id=23974

Iyengar S (1991) Is Anyone Responsible? How Television Frames Political Issues. Chicago, IL: University of Chicago Publisher.

J Craig Venter Institute (JCVI) (2010) First self-replicating synthetic bacterial cell (Press release). Available at: http://www.jcvi.org/cms/press/press-releases/full-text/article/first-self-replicating-synthetic-bacterial-cell-constructed-by-j-craig-venter-institute-researcher/home/

Joyce S, Mazza A and Kendall S (2013) Positioning Synthetic Biology-To Meet the Challenges of the 21st Century-Summary Report of a Six Academies Symposium Series. Washington, DC: Committee on Science, Technology, and Law; Policy and Global Affairs; Board on Life Sciences; Division on Earth and Life Sciences; National Academy of Engineering; National Research Council. 
Kilman L (2012) World press trends: Newspaper audience rise, digital revenues yet to follow (Press release). Available at: http://www.wan-ifra.org/press-releases/2012/09/03/world-press-trends-newspaper-audiencerise-digital-revenues-yet-to-follow

Kohlbacher F (2006) The use of qualitative content analysis in case study research. Forum: Qualitative Social Research 7(1).

Kronberger N, Holtz P and Wagner W (2012) Consequences of media information uptake and deliberation: Focus groups' symbolic coping with synthetic biology. Public Understanding of Science 21(2): $174-187$.

Kruvand M (2012) "Dr. Soundbite": The making of an expert source in science and medical stories. Science Communication 34(5): 566-591.

Kruvand M (2013) Science and humanity in the era of synthetic life. How the news media cover synthetic biology. The International Journal of Communication and Linguistic Studies 10(2): 17-27.

Li F, Owen R and Simakova E (2015) Framing responsible innovation in synthetic biology: The need for a critical discourse analysis approach. Journal of Responsible Innovation 2(1): 104-108.

Liu W and Stewart N Jr (2015) Plant synthetic biology. Trends in Plant Science 20(5): 309-317.

"Man Have Always Played God" (2010) Göteborgs posten, 10 July. Sve: "Människan har alltid lekt Gud."

"Managing life" (2010) Turun Sanomat, 15 June. FI: "Elämän Hallintaa."

Marris C (2015) The construction of imaginaries of the public as a threat to synthetic biology. Science as Culture 24(1): 83-98.

Mayring P (2000) Qualitative content analysis. Forum: Qualitative Social Research 1(2). Available at: http:// nbn-resolving.de/urn:nbn:de:0114-fqs0002204

Mayring P (2015) Qualitative content analysis: Theoretical background and procedures. In: Bikner-Ahsbahs A, Knipping C and Presmeg N (eds) Approaches to Qualitative Research in Mathematics Education. Dordrecht: Springer Netherlands, pp. 365-380.

Murcott T (2009) Journalism and society. In: Nerlich B, Elliott R and Larson B (eds) Communicating Biological Sciences: Ethical and Metaphorical Dimensions. Burlington, VT: Ashgate Publishing Company, pp. 93-107.

National Strategy for Biotechnology (NSFB) (2011-2020) For the future of value creation health and the environment. Available at: http://www.forskningsradet.no/servlet/Satellite?blobcol=urldata\&;blobhead er=application $\% 2 F p d f \& b l o b h e a d e r n a m e 1=$ Content-Disposition $\% 3$ A\&blobheadervalue $1=+$ attachment $\% 3 \mathrm{~B}+$ filename\%3DNationalStrategyforBiotechnology2011-2020.pdf\&blobkey=id\&blobtable=Mungo Blobs\&blobwhere $=1274502682687 \&$ ssbinary $=$ true

Nelson TE, Clawson RA and Oxley ZM (1997) Media framing of a civil liberties conflict and its effect on tolerance. The American Political Science Review 91(3): 567-583.

Nerlich B (2014) Synthetic biology markets: Opportunities and obstacles, 31 December. Available at: http:// blogs.nottingham.ac.uk/makingsciencepublic/2014/12/31/synthetic-biology-markets-opportunities-andobstacles/

Nerlich B, Elliott R and Larson B (2009) Communicating biological sciences: An introduction. In: Nerlich B, Elliott R and Larson B (eds) Communicating Biological Sciences: Ethical and Metaphorical Dimensions. Burlington: Ashgate Publishing Company, pp. 1-22.

Nisbet MC and Scheufele DA (2009) What's next for science communication? Promising directions and lingering distractions. American Journal of Botany 96(10): 1767-1778.

Nisbet MC, Brossard D and Kroepsch A (2003) Framing science: The stem cell controversy in an age of press/ politics. The International Journal of Press/Politics 8(2): 36-70.

Owen R, Macnaghten P and Stilgoe J (2012) Responsible research and innovation: From science in society to science for society, with society. Science and Public Policy 39(6): 751-760.

Pardo R, Engelhard M, Hagen K, Bagger Jørgensen R, Rehbinder E, Schnieke A, et al. (2009) The role of means and goals in technology acceptance-A differentiated landscape of public perceptions of pharming. EMBO Reports 10(10): 1069-1075.

Pauwels E, Lovell A and Rouge E (2012) Trends in American and European press coverage of synthetic biol$o g y$. Synthetic Biology Project, vol. Synbio 4. Washington, DC: Wilson Center.

Presidential Commission for the Study of Bioethical Issues (PCSBI) (2010) New Directions: The Ethics of Synthetic Biology and Emerging Technologies. Washington, DC: PCSBI. 
"Researchers are creating artificial life" (2010) Politiken, 20 May. Den: "Forskere skaber kunstigt liv."

"Researchers have created new life" (2010) Adresseavisen, 20 May. Nor: "Forskere har konstruert nytt liv."

Ro D-K, Paradise EM, Ouellet M and Keasling JD (2006) Production of the antimalarial drug precursor artemisinic acid in engineered yeast. Nature 440: 940-943.

Scheufele DA (1999) Framing as a theory of media effects. Journal of Communication 49(1): 103-122.

Scheufele DA and Lewenstein BV (2005) The public and nanotechnology: How citizens make sense of emerging technologies. Journal of Nanoparticle Research 7(6): 659-667.

Schmid-Petri H, Knocks S, Sager P and Silke A (2014) La Biologie Synthétique Dans la Société. Une Nouvelle Technologie Dans le Débat Public [Synthetic Biology in Society. A New Technology in the Public Debate]. Berne: TA-SWISS.

Schmidt M, Ganguli-Mitra A, Torgersen H, Kelle A, Deplazes A and Biller-Andorno N (2009) A priority paper for the societal and ethical aspects of synthetic biology. Systems and Synthetic Biology 3(1-4): $3-7$.

Schmidt M, Meyer A and Cserer A (2013) The bio: Fiction film festival: Sensing how a debate about synthetic biology might evolve. Public Understand Science. Epub ahead of print 28 October. DOI: $10.1177 / 0963662513503772$.

Scientific Committee on Emerging and Newly Identified Health Risks (SCENIHR), Scientific Committee on Health and Environmental Risks (SCHER), Scientific Committee on Consumer Safety (SCCS) (2015) Synthetic biology II—Risk assessment methodologies and safety aspects. Opinion, May. Available at: http://ec.europa.eu/health/scientific_committees/emerging/docs/scenihr_o_048.pdf

Scientific Committee on Health and Environmental Risks (SCHER), Scientific Committee on Emerging and Newly Identified Health Risks (SCENIHR) Scientific Committee on Consumer Safety (SCCS) (2014) Opinion on Synthetic Biology I. Definition. Brussels: European Commission. Available at: http:// ec.europa.eu/health/scientific_committees/emerging/docs/scenihr_o_044.pdf

"Scientist created artificial life" (2010) Aftenposten, 20 May. Nor: "Vitenskapsmann skapte kunstig liv."

SSF (2011) Sammanfattande dokument för utarbetandet av SSF:s Forskningsstrategi 2012-2017 [Summary document for the preparation of the SSF's research strategy 2012-2017]. Available at: http://www. stratresearch.se/Global/Strategiprocessen/Sammanfattande\%20dokument \%20Fas\%201\%20o2.pdf

Stilgoe J, Owen R and Macnaghten P (2013) Developing a framework for responsible innovation. Research Policy 42(9): 1568-1580. Available at: http://dx.doi.org/10.1016/j.respol.2013.05.008

Synthetic Biology Roadmap Coordination Group (2012) A Synthetic Biology Roadmap for the UK. Swindon: Technology Strategy Board.

"The Man Who Built Life" (2012) Helsingin Sanomat, 24 July. Fin: "Mies, joka rakensi elämän."

"The Midwife of Artificial Life" (2012) Aamulehti, 24 July. Fin: "Keinoelämän kätilö."

Torgersen H and Schmidt M (2013) Frames and comparators: How might a debate on synthetic biology evolve? Futures 48: 44-54.

Upham P and Dendler L (2015) Scientists as policy actors: A study of the language of biofuel research. Environmental Science \& Policy 47: 137-147. Available at: http://dx.doi.org/10.1016/j.envsci.2014.11.005

"Upheavals Tested Earth" (2010) Turun Sanomat, 28 December. "Mullistukset koettelivat Maata."

Valkenburg PM, Semetko HA and Vreese CHD (1999) The effects of news frames on readers' thoughts and recall. Communication Research 26(5): 550-569.

Venter JC (2010) Craig Venter: Watch me unveil "synthetic life." TED conferences. Available at: http:// www.ted.com/talks/craig_venter_unveils_synthetic_life?language $=$ en

Von Schomberg R (2011) Prospects for technology assessment in a framework of responsible research and innovation. In: Dusseldorp M and Beecroft R (eds) Technikfolgen Abschätzen Lehren: Bildungspotenziale Transdisziplinärer [Evaluations Judge Teaching: The Potentiality of Transdisciplinary Education]. Wiesbaden: Vs Verlag. Methoden, pp. 39-62.

Von Schomberg R (2013) A vision of responsible research and innovation. In: Owen R, Bessant J and Heintz $\mathrm{M}$ (eds) Responsible Innovation: Managing the Responsible Emergence of Science and Innovation in Society. Hoboken: Wiley, pp. 51-74.

"Wanted: Surrogate mother to Neanderthal baby" (2013) Berlingske, 20 January. Den: "Søges: Rugemor til neandertalerbaby." 


\section{Author biographies}

Mirko Ancillotti studied philosophy at the University of Pisa, Italy. He is currently employed as Research Assistant working on a project on synthetic biology outreach and the way it is popularized by scientists and the media. Since 2015, he started working also on a project on the ELSI of antibiotic resistance and alternative antibiotic treatments.

Niklas Holmberg, ThM, is a ThD student in Theological Ethics and Philosophy of Religion at Åbo Akademi University, Finland. His research interests include public understanding of synthetic biology and the fears and hopes connected to it.

Mikael Lindfelt is a Professor in Theological Ethics and Philosophy of Religion at Åbo Akademi University, and currently leader of a subproject addressing transparent strategies for ethical questions and communication in handling synthetic biology's within the project Artfilm-Fabricating bacterial biofilms via artificial nano(bio)components, a project funded by the Academy of Finland.

Stefan Eriksson, $\mathrm{PhD}$, is an Associate Professor of research ethics at Uppsala University, a senior lecturer at the Centre for Research Ethics \& Bioethics, Uppsala University, and serves as editor of the Swedish Research Council's website CODEX. His research interests are autonomy and informed consent, dual use research, the regulation of research and publication ethics. 